Eur. J. Clin. Chem. Clin. Biochem.

Vol. 30, 1992, pp. $301-305$

(C) 1992 Walter de Gruyter \& Co. Berlin $\cdot$ New York

\title{
A Time-Resolved Fluoroimmuno Assay of the IgM-Rheumatoid Factor
}

\author{
By G. van der Sluijs Veer and J.W. P. H. Soons \\ Klinisch Chemisch Laboratorium, Medisch Spectrum Twente, Enschede, The Netherlands
}

(Received October 9, 1991/January 27, 1992)

Summary: A time-resolved fluoroimmuno assay of the IgM-rheumatoid factor is described. Aggregated rabbit IgG was coated to microtitre plates to serve as the target protein. $\mathrm{F}\left(\mathrm{ab}^{\prime}\right)_{2}$-fragments from antibodies, raised in rabbits against human IgM, were labelled with $\mathrm{Eu}^{3+}$ and used in the assay to mark the bound IgMrheumatoid factor. The labelling procedure is easy to perform, and there is no need for special equipment. The shelf life of the label at $-20^{\circ} \mathrm{C}$ is at least one year. The lower detection limit of the assay is $1.3 \times$ $10^{3} \mathrm{IU} / \mathrm{l}$. The range over which the IgM-rheumatoid factor can be measured at a within-run precision of $<5 \%$ without varying the dilution (working range) is $5-1200 \times 10^{3} \mathrm{IU} / \mathrm{l}$. Linearity in serum dilutions is good. There is good correlation with existing methods for the assay of IgM-rheumatoid factor. This correlation is better with an assay using rabbit IgG as the target than with one using human IgG. Comparison of methods shows that standardization, despite the use of the WHO Reference Preparation as the first calibrator, remains problematic. The 95th percentile in normal bloodbank donors is $8 \times 10^{3} \mathrm{IU} / \mathrm{l}$. The costs for the reagents were about 0.5 Dutch florin (ca 0.30 US-\$) per well. In conclusion, the method described here is analytically at least comparable with other methods, in precision, linearity, working range etc. Finally, it is easy to perform.

\section{Introduction}

Since the introduction of the Waaler-Rose test in the 1940 's, the estimation of rheumatoid factor has been one of the cornerstones in the diagnosis of rheumatoid arthritis. This is confirmed in the criteria of the American Rheumatism Association (1). For a long period of time, the techniques for the estimation of rheumatoid factor remained relatively unchanged. The Waaler-Rose test or latex-fixation test, which measures serial dilutions of patient serum, is still widely used. Inter-laboratory variability was reduced by the introduction of the International Unit, defined by the International Reference Preparation (IRP) of the World Health Organization (WHO) (2). However, as a consequence of the generally used semi-quantitative methods, values for rheumatoid factor were still reported in steps differing by a factor of two. This leads to artificially high inter-laboratory variation. The development of immunoassays introduced the possibility of fully quantitative determinations of the rheumatoid factor, and the opportunity to further reduce the inter-laboratory variation. Moreover, these assays were specific for the rheumatoid factors of different immunoglobulin classes. Many different methods came commercially available, especially for estimating the IgM-type rheumatoid factor. The most widely used are nephelometry (3) and enzyme linked immunosorbent assay (Elisa) (4).

However, within-run coefficients of variation (CV's) of $>10 \%$, which in our opinion are analytically unacceptable, are not uncommon in these assays, especially at high and low concentrations. Furthermore, the limited working range often makes it necessary to assay the patient sera in different dilutions. Our experience with other assays showed that the technique of the time-resolved fluoroimmuno assay, as used in the Delfia ${ }^{\text {tm }}$ system (Pharmacia, Turku, Finland), could possibly overcome these disadvantages. Since there is no immediate prospect of a commercial kit appearing on the market, we decided to design our own assay, including the labelling of a tracer with europium. We describe here this time-resolved fluoroimmuno assay for the IgM-type rheumatoid factor. It is easy to perform and cost effective. 


\section{Materials and Methods}

Reagents

Phosphate-buffered saline: $9 \mathrm{~g} / \mathrm{l} \mathrm{NaCl}, 10 \mathrm{mmol} / \mathrm{l}$ phosphate, $\mathrm{pH}=7.4$.

Coating buffer: phosphate-buffered saline containing $5 \mathrm{~g} / \mathrm{l}$ bovine serum albumin, fatty acid-free (Sigma, St. Louis MO, USA) and $7.7 \mathrm{mmol} / 1 \mathrm{NaN}_{3}$.

Assay buffer: phosphate-buffered saline containing $5 \mathrm{~g} / \mathrm{l}$ bovine serum albumin, fatty acid-free (Sigma) and $200 \mu \mathrm{l} / 1$ Tween-20 ${ }^{\text {tm }}$ (Merck, Darmstadt, Germany).

Washing buffer: $9 \mathrm{~g} / \mathrm{l} \mathrm{NaCl}, 20 \mathrm{mmol} / \mathrm{l}$ TRIS-HCl, $7.7 \mathrm{mmol} / \mathrm{l}$ $\mathrm{NaN}_{3}$ and $200 \mu \mathrm{l} / \mathrm{l}$ Tween-20 $0^{\mathrm{tm}}, \mathrm{pH}=7.8$.

Coating solution: $25 \mathrm{mg}$ rabbit IgG (Nordic, Tilburg, The Netherlands) was dissolved in $2 \mathrm{ml}$ demineralized water. To accomplish aggregation of the IgG, this solution was incubated 20 min at $63{ }^{\circ} \mathrm{C}$. Subsequently, it was diluted in phosphatebuffered saline to give a stock solution of $1.25 \mathrm{~g} / \mathrm{l}$, portions of which were stored at $-20^{\circ} \mathrm{C}$. The coating was performed at a final concentration of aggregated rabbit $\mathrm{IgG}$ of $25 \mathrm{mg} / \mathrm{l}$ in phosphate-buffered saline.

Solid phase: high-binding, flat-bottomed polystyrene microtitre plates (Greiner, Alphen a/d Rijn, The Netherlands) were coated by incubating the wells overnight at room temperature with $100 \mu \mathrm{l}$ of coating solution. Subsequently, the excess was removed. Some of the plates were freshly used. To assess the choice of storage conditions, the remaining plates, at this state of preparation, were divided in two lots. The first lot was stored at $4{ }^{\circ} \mathrm{C}$ in a humidified atmosphere for $1-12$ weeks, the second at $-20^{\circ} \mathrm{C}$ for $1-12$ weeks. Before use, a second coating with bovine serum albumin was performed on the fresh and the stored plates by incubating the wells with $200 \mu$ l coating buffer for 2 hours at room temperature.

Labelled antibody: $\mathrm{F}\left(\mathrm{ab}^{\prime}\right)_{2}$-fragments from antibodies raised in rabbits against human IgM (Dako A/S, Glostrup, Denmark) were labelled with $\mathrm{Eu}^{3+}$, using the labelling reagent (Pharmacia, Turku, Finland), containing N-1-(p-isothiocyanatophenyl) diethylene-triamine- $\mathrm{N}^{1}, \mathrm{~N}^{2}, \mathrm{~N}^{3}$-tetraacetate. The labelling procedure and the method for estimating the labelling index are described elsewere (5). In short: a fifty-fold molar excess of the labelling reagent was incubated overnight at room temperature with the $F\left(a b^{\prime}\right)_{2}$-fragments. The labelled fraction was isolated by gel filtration (PD-10 column). A solution of $0.80 \mathrm{~g} / 1$ labelled antibody with a labelling index of $5.5 \mathrm{~mol}$ europium per mol antibody was obtained. This preparation was used in the experiments described, at a final concentration of $1.6 \mathrm{mg} / \mathrm{l}$ in assay buffer. The labelled antibody was stored at $-20^{\circ} \mathrm{C}$. The shelf life under these conditions is at least one year.

Enhancement solution (Pharmacia, Turku, Finland): $6.8 \mathrm{mmol} /$ potassium hydrogen phthalate, $100 \mathrm{mmol} / \mathrm{l}$ acetic acid, 50 $\mu \mathrm{mol} / 1$ tri- $n$-octylphosphine oxide, $15 \mu \mathrm{mol} / 1$ 2-naphthoyltrifluoro-acetone and $1 \mathrm{~g} / 1$ Triton X-100.

\section{Calibrators}

For the calibration we used the Dutch National Reference Preparation (DNRP) (Foundation Reference Laboratory of Rheumatoid Serology (RELARES), Amsterdam, The Netherlands), which is calibrated against the International Reference Preparation (IRP) of Rheumatoid Arthritis Serum (World Health Organization WHO), and contains 200 IU per ampoule IgM-rheumatoid factor (6). This preparation was dissolved in distilled water and diluted in assay buffer to obtain a set of calibrating solutions covering the concentration range 5 to 1200 $\times 10^{3} \mathrm{IU} / \mathrm{l}$. As a check, we determined the IgM-rheumatoid factor concentration of the Dutch National Reference Preparation against the International Reference Preparation of the
WHO by the time-resolved fluoroimmuno assay. One ampoule of the WHO International Reference Preparation was donated by RELARES. It was reconstituted in $1 \mathrm{ml}$ distilled water. This solution contains $100 \times 10^{3} \mathrm{IU} / 1$ by definition.

\section{Samples}

For the estimation of the between-run precision, five patient sera were selected with low, intermediate and high concentrations of IgM-type rheumatoid factor. Aliquots were stored at $-20^{\circ} \mathrm{C}$. For the comparison between the different IgM-rheumatoid factor assays, sera were selected from patients suspected of suffering from rheumatoid arthritis. These sera were stored at $-20^{\circ} \mathrm{C}$ before the assay.

\section{Methods}

The assay was performed at room temperature and consisted of:

1) $2 \mathrm{~h}$ incubation of the coated microtitre well with $100 \mu \mathrm{l}$ of the calibration solutions, samples (diluted 1:500 in assay buffer), or blank (assay buffer), in duplicate;

2) six washing steps with washing buffer;

3) incubation with the labelled antibody with slow shaking for $2 \mathrm{~h}$;

4) six washing steps with washing buffer;

5) addition of $100 \mu$ of the enhancement solution;

6) measurement of the time resolved fluorescence with the Arcus Fluorometer (Pharmacia, Turku, Finland)

The efficiency of the binding of IgM-rheumatoid factor to the solid phase was tested as follows: after step 1 of the assay procedure, the fluid from the well was pipetted into a second, fresh well and further assayed. This enables both the direct measurement of the bound IgM-rheumatoid factor in the first well and the residual IgM-rheumatoid factor in the second. From these results the percentage bound to the first well can be calculated.

For the method comparison the rheumatoid factor was also measured by Elisa (Malakit IgM-rheumatoid factor IgM anti rabbit IgG, Biolab, Wavre, Belgium) and by rate nephelometry with aggregated human IgG as the antigen $\left(\mathrm{RHF}^{\mathrm{tm}}\right.$-kit on an ARRAY-analyzer, Beckman, Brea CA, USA), according to the instructions of the manufacturers. Results were calculated based on the standards delivered with the kits. The statistical analysis was performed according to Passing \& Bablok (7)

\section{Results}

The mean labelling index $(\mathrm{N}=4)$ was $5.5 \mathrm{~mol} / \mathrm{mol}$ (range $5-6 \mathrm{~mol} / \mathrm{mol}$ ).

The efficiency of the binding of the IgM-rheumatoid factor to the solid phase was $93 \pm 5 \%$ (mean \pm SD) in the sera tested $(\mathrm{N}=7)$. The efficiency was not concentration-dependent in the range tested (26$\left.1233 \times 10^{3} \mathrm{IU} / \mathrm{l}\right)$. We found no significant deviation in the IgM-rheumatoid factor concentration of the Dutch National Reference Preparation from the 200 $\times 10^{3} \mathrm{IU} / 1$ established by the manufacturer, when we measured it against the WHO International Reference Preparation under the conditions of the assay described. 


\section{Assay characteristics}

The lower detection limit was estimated by replicate analysis $(\mathrm{N}=10)$ of the assay buffer. It was defined as the IgM-rheumatoid factor corresponding to the mean +3 SD response of the assay buffer. The limit found was $1.3 \times 10^{3} \mathrm{IU} / 1$.

The within-run precision was estimated by measuring 9 patient sera with different IgM-rheumatoid factor in replicate $(\mathrm{N}=8)$. The precision profile is shown in figure 1. The IgM-rheumatoid factor can be measured at an acceptable precision of $<5 \%$, without varying the dilution factor, in the range $5-1200$ $\times 10^{3} \mathrm{IU} / 1$

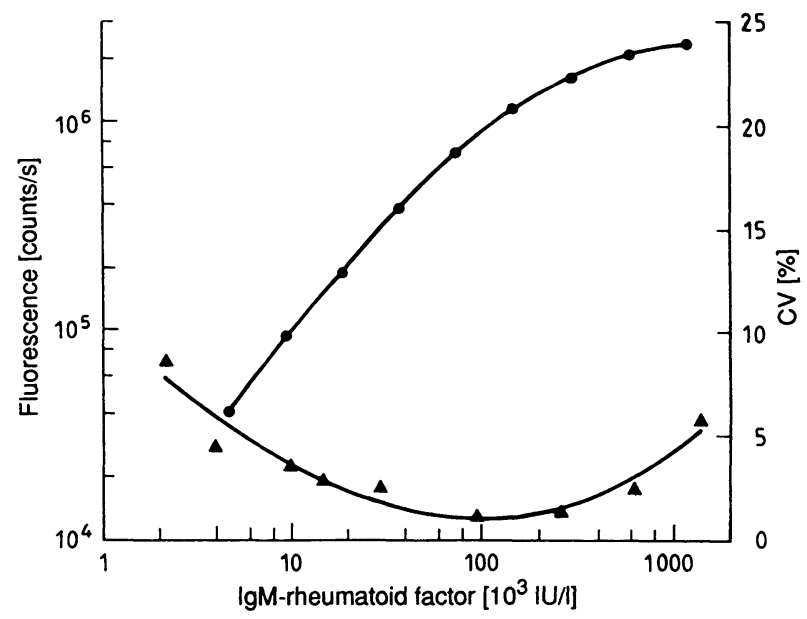

Fig. 1. Calibration curve and precision profile.

Calibration curve (circles): fluorescence at varying IgMrheumatoid factor concentrations. Precision profile (triangles): IgM-rheumatoid factor concentration of nine patient sera were measured in replicate $(N=8)$. The coefficients of variation were plotted against the mean concentrations (triangles).

Between-run precision was compared for plates that were precoated batchwise with $\mathrm{IgG}$, then stored, and for freshly prepared plates; the results are shown in table 1 . The between-run precision was estimated by measuring five patient sera in duplicate in eight runs for the three storage conditions of the microtitre plates.

Tab. 1. Between-run CV's under different conditions of microtitre plate storage. For each condition, the IgM-rheumatoid factor concentrations of the 5 patient sera were measured in 8 runs. For further experimental details see Materials and Methods.

\begin{tabular}{llll}
\hline $\begin{array}{l}\text { Mean con- } \\
\text { centration } \\
\left(10^{3} \mathrm{IU} / \mathrm{l}\right)\end{array}$ & \multicolumn{3}{l}{ Coefficient of variation $(\%)$} \\
\cline { 2 - 4 } & fresh made & stored $4{ }^{\circ} \mathrm{C}$ & stored $-20^{\circ} \mathrm{C}$ \\
\hline 9 & 19.7 & 13.0 & 14.4 \\
13 & 15.5 & 4.3 & 4.5 \\
76 & 26.0 & 9.9 & 16.7 \\
245 & 9.4 & 4.8 & 8.2 \\
404 & 20.2 & 10.8 & 12.6 \\
\hline
\end{tabular}

Linearity was tested in two ways. A serum sample with a high IgM-rheumatoid factor was diluted serially with a) the assay buffer, b) a serum with a low IgM-rheumatoid factor, and assayed as a sample. The results are shown in figure 2.

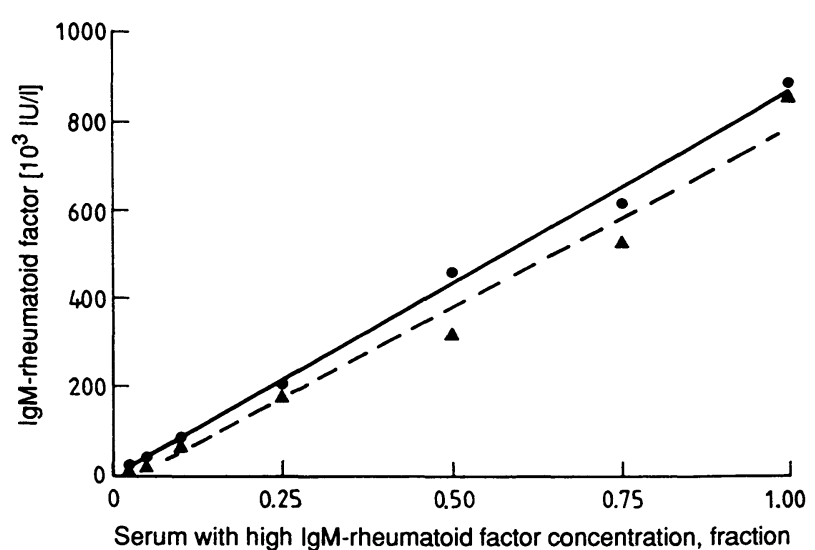

Fig. 2. Linearity.

A serum sample with a high IgM-rheumatoid factor concentration was diluted serially with

a) assay buffer (circles),

b) a serum with a low IgM-rheumatoid factor concentration (triangles).

The measured IgM-rheumatoid factor concentration was plotted against the fraction of the high IgM-rheumatoid factor serum.

In normal healthy blood bank donors $(\mathrm{N}=33)$ $8 \times 10^{3} \mathrm{IU} / 1$ was established as the 95 th percentile of the IgM-rheumatoid factor concentration.

\section{Comparison with other methods}

The correlation between the results of the different quantitative methods tested, is shown in figures $3 \mathrm{a}$ and $3 b$.

The regression between the time-resolved fluorescence (x) and the Elisa (y) was: $\mathrm{y}=1.65 \mathrm{x}-19.42$. The slope shows a significant deviation from 1 . The $y-$ intercept is not significantly different from zero $(p<0.05)$. The coefficient of correlation was 0.95 .

The regression between the time-resolved fluorescence $(\mathrm{x})$ and the rate nephelometry $(\mathrm{z})$ was: $\mathrm{z}=0.98 \mathrm{x}$ +4.09 . Slope and $z$-intercept do not deviate significantly from 1 and zero, respectively $(p<0.05)$. The coefficient of correlation was 0.88 .

\section{Costs}

The costs for reagents were only about $\mathrm{HFl} 0.50$ (ca. 0.30 US-\$) per well. 

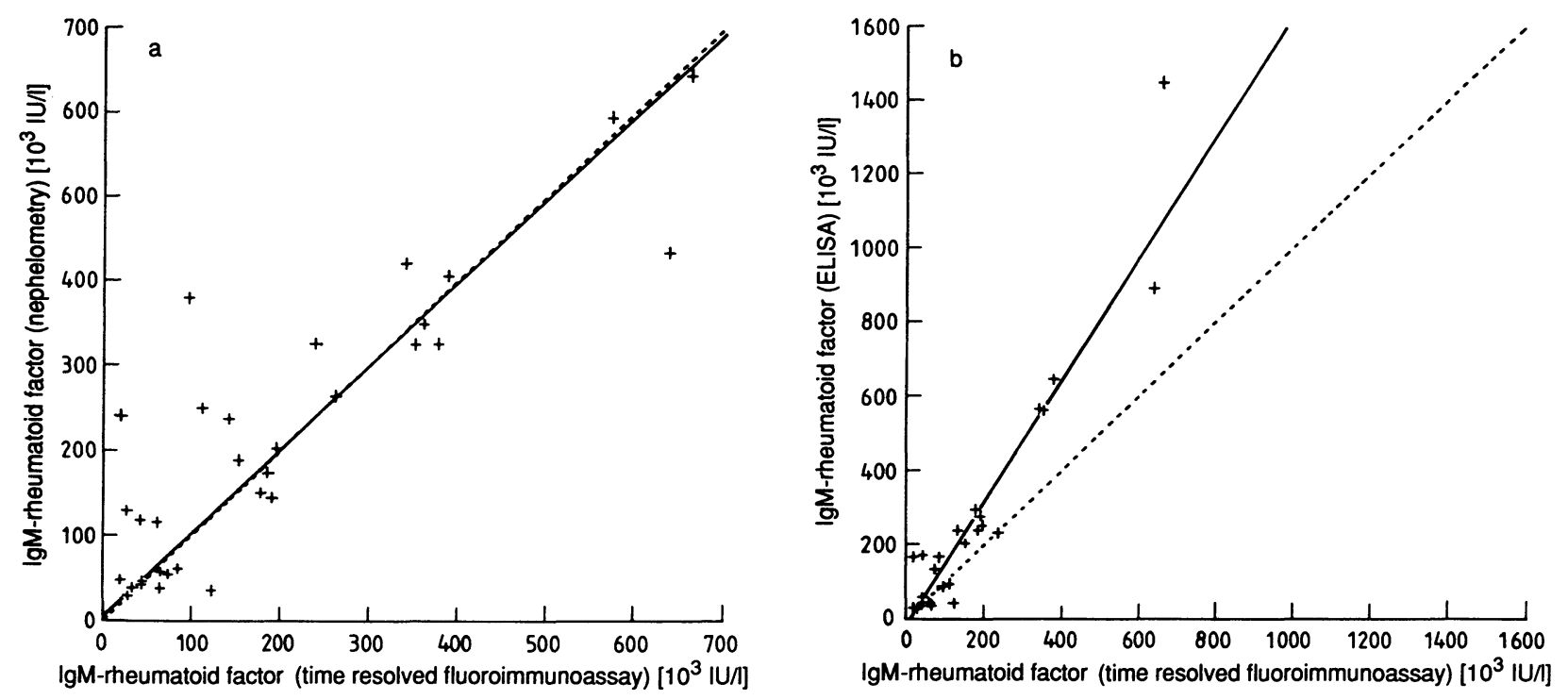

Fig. 3. Assay comparison.

Figure 3a shows the comparison of the results obtained by nephelometry and the time-resolved fluoroimmuno assay. Sera of 33 patients were measured in both assays.

$y=0.98 x+4.09$

Figure $3 \mathrm{~b}$ shows the comparison of the Elisa and the time-resolved fluoroimmuno assay. The results of 27 patient sera, obtained in both assays were plotted.

$\mathrm{y}=1.65 \mathrm{x}-19.42$

Regression analysis was performed according to Passing \& Bablok (7).

\section{Discussion}

Many combinations of components are possible for an assay of the IgM-rheumatoid factor. With respect to the target antigen, there is much discussion in the literature about the use of $\operatorname{IgG}$ of human or rabbit origin. Human IgG possibly better reflects the in vivo situation. On the other hand, rabbit IgG, the antigen in the classic Waaler-Rose test, is more specific for rheumatoid arthritis (8). For this reason we prefer the rabbit IgG. To increase the avidity of the IgM-rheumatoid factor for the antigen, we used the aggregated form of the IgG (9).

The decision to use only the $\mathrm{F}\left(\mathrm{ab}^{\prime}\right)_{2}$-fragment of an antibody against human IgM as the tracer is dictated by the fact that the rheumatoid factors, irrespective of the immunoglobin class to which they belong, must not bind to a Fc fragment of this antibody; this would give false results.

On the basis of the results in table 1 , we choose to store the batchwise precoated microtitre plates at $4{ }^{\circ} \mathrm{C}$ in a humidified atmosphere, for routine use. Although a between-run precision up to $13 \%$ in IgM-rheumatoid factor assays is not uncommon $(3,10,11)$, we think that the high ratio between between-run and within-run precision suggests that a decrease of the between-run CV can be achieved. Therefore, we investigated the effect of performing the second coating with bovine serum albumin, batchwise, before the storage, instead of afterwards. This even worsened the CV's (results not shown). Further studies on the preservation and storage of the plates, to improve the between-run precision, are under investigation.

In the comparison between the described assay and nephelometry, it can be seen that in many patients the rheumatoid factors are different. This is not surprising because the two methods differ markedly in the detection technique, the antigen used etc. The correlation with the Elisa is better. Here, a comparable antigen, namely from rabbit, is used and both assays are IgM specific. The slope of the regression line of 1.65 , significantly deviating from 1 , can be ascribed to the standardization, in spite of the fact that both assays are calibrated on the same International Reference Preparation from the World Health Organization. A comparable conclusion has been published by Jaspers et al. (10). It can be explained by the fact that the IgM-rheumatoid factor in the International Reference Preparation is, as a consequence of its polyclonal source, a mixture of different IgM molecules, each with its own characteristics, such as avidity, specificity etc. The same holds for the Dutch National Reference Preparation, and of course for the patient sera. Standardizing one mixture against another is of course not allowed theoretically, but it is not always avoidable at the present state of the art. We agree with the suggestion of Høier-Madsen et al. (11) that, at present, the only way to obtain compar- 
able results between laboratories seems to be the use of the same method. A disadvantage of this approach, however, is that it does not stimulate research and marketing to introduce better methods.

We were not able to estimate the 95th percentile in a group of control subjects as defined by the American Rheumatism Association (1). We found a value of $8 \times 10^{3} \mathrm{IU} / 1$ in healthy blood bank donors. This is comparable with the finding of others (12). The value given here can only be considered as an indication of a reference value, because the group tested is not a matched control group. It does demonstrate, however, that normal people have detectable IgM-rheumatoid factor concentrations.

In our laboratory, we use the generally accepted $20 \times 10^{3} \mathrm{IU} / 1$ as the cut-off limit for pathology. Results between 8 and $20 \times 10^{-3} \mathrm{IU} / 1$ can be considered as suspect. Perhaps these patients have an enhanced chance of subsequently developing rheumatoid arthritis. Because of its technical advantages, such as low background, high precision, large working range and long shelf life of the label, the technique of the time-resolved fluoroimmuno assay has established its position in the field of binding analysis. The IgMrheumatoid factor assay described here has these same advantages. The one-site preparation of europium labels is not yet practised widely in routine clinical laboratories. It should be stressed, that the procedure is very simple and therefore deserves more attention. On site labelling is possible in any normally equipped laboratory. The reagent costs of the assay are low, mainly because of the long shelf-life and low consumption of the labelled antibody.

In conclusion, the method described here is analytically at least comparable with other methods, in detection limit, precision, linearity, working range etc. It is cheap and easily to perform in practice.

\section{Acknowledgement}

The authors thank Dr T. J. Penders and $\operatorname{Mr} C$.W. Weykamp from the laboratory of the Koningin Beatrix Ziekenhuis (Winterswijk, The Netherlands) for valuable discussions.

\section{References}

1. Arnett, F. C., Edworthy, S. M., Bloch, D. A., McShane, D. J., Fries, J. F., Cooper, N. S., Healy, L. A., Kaplan, S. R., Liang, M. H., Luthra, H. S., Medsger, T. A. Jr., Mitchell, D. M., Neustadt, D. H., Pinals, R. S., Schaller, J. G., Sharp, J. T., Wilder, R. L. \& Hunder, G. G. (1988) The American Rheumatism Association 1987 revised criteria for the classification of rheumatoid arthritis. Arthritis Rheum. 31, 315-324.

2. Anderson, S. G., Bentzon, M. W., Houba, V. \& Krag, P. (1970) International Reference Preparation of Rheumatoid Arthritis Serum. Bull. WHO 42, 311-318.

3. Roberts-Thomson, P. J., McEnvoy, R., Langhans, T. \& Bradley, J. (1985) Routine quantification of rheumatoid factor by nephelometry. Ann. Rheum. Dis. 44, 379-383.

4. Bampton, J. L. M., Cawston, T. E., Kyle, M. V. \& Hazleman, B. L. (1985) Measurement of rheumatoid factors by an enzyme-linked immunosorbent assay (ELISA) and comparison with other methods. Ann. Rheum. Dis. 44, 13-19.

5. Lanthanide labelling for time-resolved fluorometry (1990). Pharmacia/Wallac Oy, Turku, Finland.

6. Feltkamp, T. E. W. (1988) Expression of Rheumatoid Factors in Titres or Units? Scand. J. Rheumatology, Suppl. 75, $54-57$.
7. Passing, H. \& Bablok, W. (1983) A New Biometrical Procedure for Testing the Equality of Measurements from Two Different Analytical Methods. Application of linear regression procedures for method comparison studies in Clinical Chemistry, Part I. J. Clin. Chem. Clin. Biochem. 21, 709720 .

8. Carson, D. A. (1985) Rheumatoid Factor. In: Textbook of Rheumatology (Kelley, W. N., Harris, E. D., Ruddy, S. \& Sledge, C. B., eds.) pp. 664-679, Saunders Co., Philadelphia, PA, USA.

9. Schrohenloher, R. E. (1988) IgG as Antigen in Human Rheumatoid Disease. Scand. J. Rheumatology, Suppl. 75, $133-139$.

10. Jaspers, J. P. M. M., Van Oers, R. J. M. \& Leerkes, B. (1988) Nine Rheumatoid Factor Assays Compared. J. Clin. Chem. Clin. Biochem. 26, 863-871.

11. Høier-Madsen, M., Grunnet, N. \& Wiik, A. (1988) A Danish Inter-Laboratory Study of IgM Rheumatoid Factor (RF) Determined by Enzyme-Linked Immunosorbent Assay (ELISA). Scand. J. Rheumatology, Suppl. 75, 50-53.

12. Leeuwen, M. A. van, Westra, J., Limburg, P. C., Jong, H. J. de, Marrink, J. \& Rijswijk, M. H. van (1988) Quantitation of IgM, IgA, and IgG Rheumatoid Factors by ELISA in Rheumatoid Arthritis and other Rheumatic Disorders. Scand. J. Rheumatology, Suppl. 75, 25-31.

G. van der Sluijs Veer

Klinisch Chemisch Laboratorium

Medisch Spectrum Twente

Postbus 50.000

NL 7500 KA Enschede 
